\title{
Wyspa klucz Małgorzaty Szejnert wobec amerykańskiego mitu równości, wolności i sukcesu
}

\author{
Key Island by Małgorzata Szejnert towards the American \\ myth of equality, freedom and success
}

\author{
||Magdalena Gajek
Uniwersytet im. Adama Mickiewicza w Poznaniu
}

\begin{abstract}
The article is an analysis of the values that create the American Dream in Key Island historical reportage written by Malgorzata Szejnert. Equality, freedom and success were the hallmarks of New World, attracting millions of Europeans at the turn of the century. Most of them went to Ellis Island, where the immigration center was. The selection of immigrants, the limitations of their freedom, and their ambivalent successes illustrate, how unrealistic were the American ideals of democracy. The article acknowledges Ellis Island as the "site of memory” in the sense given by Pierre Nora.
\end{abstract}

Key words: Malgorzata Szejnert, reportage, Ellis Island, United States of America, American Dream, emigration

Streszczenie: Artykuł stanowi analizę wartości tworzących amerykański mit w reportażu historycznym Małgorzaty Szejnert Wyspa klucz. Równość, wolność i sukces, z których słynął Nowy Świat, przyciągały miliony Europejczyków za ocean na przełomie XIX i XX wieku. Większość z nich przeszła kontrolę na Ellis Island, gdzie znajdowało się centrum imigracyjne. Reportaż, prezentując różne wymiary selekcji imigrantów, ograniczenia ich wolności oraz ambiwalentne sukcesy, obrazuje, jak nieprzystający do rzeczywistości był amerykański ideał demokracji. Artykuł uznaje Ellis Island za tzw. miejsce pamięci w rozumieniu, jakie nadał temu pojęciu Pierre Nora.

Słowa kluczowe: Małgorzata Szejnert, reportaż, Ellis Island, Stany Zjednoczone Ameryki, amerykański mit, emigracja

Emigracja od zawsze wiązała się głównie z przymusem, próbą ucieczki do lepszego świata spowodowaną trudną sytuacją ekonomiczną, represjami politycznymi, religijnymi, konfliktami zbrojnymi czy brakiem podstawowych środków do życia. Bez względu na powód ludzie szukali w nowym miejscu dobrobytu, spokoju i wolności. Z tego względu podejmowali dalekie wyprawy w nieznane, porzucali rodzinę, ojczyznę, dotychczasowe przyzwyczajenia, a nawet ryzykowali życie. 
Imigracja wpływa nie tylko na migrujących, ale także na ludność krajów, do których nowe społeczności przybywają. Prawdopodobnie właśnie z tego powodu jest to zjawisko analizowane przez różne grupy ekspertów: demografów ${ }^{1}$, socjologów ${ }^{2}$, pedagogów ${ }^{3}$ czy psychologów ${ }^{4}$. Zagadnienie naświetla również literatura, czego przykładem jest Wyspa klucz Małgorzaty Szejnert. Reportaż opowiada o falach emigracji do Stanów Zjednoczonych w XIX i XX wieku, kiedy na Ellis Island funkcjonował punkt przyjmowania docierających do Wschodniego Wybrzeża imigrantów czy uchodźców.

Migracja w USA jest zagadnieniem szczególnym. Napływ obcokrajowców do Nowego Świata miał w Ameryce zupełnie inny wymiar niż w Europie. Podkreśla to holenderski filozof i profesor urbanistyki - Paul Scheffer w pracy Druga ojczyzna. Imigranci w społeczeństwie otwartym:

Imigracja na starym kontynencie przybrała spore rozmiary, gdy formowanie narodów było już w zaawansowanym stadium, podczas gdy po drugiej stronie oceanu przybywanie imigrantów wplatano w opowieść Amerykanów o własnym kraju. Ta różnica jest niezaprzeczalna i ma wielkie znaczenie dla postawy wobec imigracji (Scheffer 2010, 374).

O przynależności do społeczeństwa amerykańskiego decydowało wyznawanie przyjętych na mocy umowy społecznej wzorców oraz wiara we wspólne wartości. Miejsce urodzenia oraz więzy rodzinne nie warunkowały tego, czy ktoś mógł uznawać się za Amerykanina, czy nie. Kiedy w Europie za ojczyznę uważano kraj urodzenia, a za rdzennych mieszkańców tych żyjących na danych ziemiach od pokoleń, za oceanem przynależność do grupy obywateli USA była wyborem i świadomą decyzją. W związku z tym, że Stany Zjednoczone jako państwo dopiero się tworzyły, obywateli nie łączyła historia przodków, wspólne dzieje czy tradycje. Państwowość opierała się na integracji wokół idei bycia Amerykaninem osób o różnym pochodzeniu i wyrosłych w odmiennych kręgach kulturowych. Nowy Świat powstał zatem na zasadzie kontrastu do borykającej się z problemami wewnętrznymi Europy, a Stany wydawały się atrakcyjniejsze niż podzielone narody Starego Kontynentu (Scheffer 2010, 551). Amerykański politolog - Samuel Huntington - podkreśla, że w Europie to przywódcy polityczni tworzyli państwo, aby kolejno przekształcić swoich poddanych w naród. W Ameryce do powstania wśród ludzi wspólnej świadomości doprowadziło zbiorowe doświadczenie oraz przywództwo rozproszonych elit, co w dalszej kolejności przełożyło się na wywalczenie niepodległości oraz „minimalistyczny zestaw centralnych instytucji politycznych” (Huntington 2007, 108).

\footnotetext{
1 Zob. Iglicka Krystyna, 2008, Kontrasty migracyjne Polski: wymiar transatlantycki, Warszawa.

2 Zob. Kawczyńska-Butrym Zofia, 2009, Migracje. Wybrane zagadnienia, Lublin.

3 Zob. Procesy migracji $w$ społeczeństwie otwartym. Perspektywa edukacji międzykulturowej, 2009, Nikitorowicz J., Misiejuk D. (red.), Białystok.

${ }_{4}$ Zob. Kubitsky Jacek, 2012, Psychologia migracji, Warszawa.
} 


\section{Dlaczego Ameryka?}

Masową migrację za ocean dzieli się na trzy fazy: lata 1830-1860, kiedy do Ameryki przybywali głównie imigranci z Niemiec, Norwegii, Belgii, Holandii oraz Irlandii, lata 1860-1900 z przeważającą liczbą Niemców, Anglików i Skandynawów oraz lata 1890-1914, kiedy przypływać zaczęli przedstawiciele bardziej różnorodnych kultur: Słowianie, mieszkańcy różnych rejonów Morza Śródziemnego oraz ludność z Bliskiego Wschodu (Osiatyński 1971, 60).

Centrum kontroli imigrantów na Ellis Island działało w okresie 18921942, co oznacza, że przyjmowało głównie drugą i trzecią falę emigracji, z dużym naciskiem na tę z krajów słowiańskich i południowych. Kolejno wyspa stała się miejscem deportacji, przetrzymywania uchodźców oraz enemy aliens (wrogich cudzoziemców, np. osób pochodzących z krajów, z którymi Stany Zjednoczone walczyły podczas II wojny światowej). Obecnie na Ellis Island znajduje się muzeum. Szejnert w swoim reportażu uwzględnia nie tylko kluczowy dla wyspy okres funkcjonowania jej jako centrum imigracyjnego, ale także nowszą historię tego miejsca.

Według Wiktora Osiatyńskiego głównymi czynnikami tworzącymi mitologię USA są ekspansja na Zachód oraz właśnie imigracja (Osiatyński 1971, 34). Oba te zagadnienia ściśle łączą się ze sobą - to niezaludnione i „niczyje” ziemie czekające na farmerów były jednym z głównych czynników przyciągających pierwsze grupy Europejczyków. Bogactwo naturalne tych terenów znacząco przyczyniło się do dynamicznego rozwoju USA. Stopniowo zasiedlane terytorium od Wschodniego do Zachodniego Wybrzeża wiązało się z migracją wewnętrzną ludności już osiadłej na Nowym Kontynencie. Żyzna ziemia wpływała także na tworzenie się mitu konserwatywnego Południa. Jak podkreśla polski politolog - Tomasz Żyro - kontrapunktem dla utopijnej, demokratycznej i pozbawionej nierówności społecznych wizji Stanów proponowanej przez Jeffersona były arkadyjskie stany południowe. Postrzegano je jako równie utopijną, idylliczną krainę, gdzie plantator zapewniał niewolnikom bezpieczeństwo, a wszystkie grupy społeczne żyły bez konfliktów w sielskim krajobrazie, pracując dla wspólnych korzyści (Żyro 1994, 117).

Poza ziemią oddawaną na własność uchodźcom i prześladowanym szczególnie rewolucyjny był system polityczny, czyli demokracja gwarantująca wolność i równość wszystkich obywateli bez względu na status społeczny, materialny, wyznanie religijne czy pochodzenie. Finalnym odzwierciedleniem tej idei stała się Deklaracja niepodległości Stanów Zjednoczonych. Był to model inny niż ten, który istniał w świadomości większości Europejczyków przybywających do Nowego Świata: „Europa reprezentowała władzę absolutną i ucisk moralny, brak wolności i prześladowania..." (Scheffer 2010, 378). Wiara w demokrację przekładała się także na ufność, że amerykańskie instytucje państwowe będą pomagały obywatelom w rozwoju i utrzymaniu własności, a także pozwolą czerpać zyski z wykonanej pracy. 
Istotnym elementem mitu jest sukces utożsamiany $\mathrm{z}$ bogaceniem się. Max Weber w swojej pracy Etyka protestancka a duch kapitalizmu wykazuje, że rozwój kapitalizmu w państwach zachodnich wypływał m.in. z purytańskiego pojęcia zawodu oraz ascetycznego sposobu życia protestantów. Wykonywanie obowiązków zawodowych, co było równoznaczne z gromadzeniem pieniędzy, nakazywała religia: „Praca wszakże jest ponadto przede wszystkim przepisanym przez Boga celem całego życia. (...) Niechęć do pracy jest oznaką braku stanu łaski" (Weber 2010, 114). Sukces materialny był więc świadectwem poprawnego wykonywania obowiązków względem Boga. Idee te przyświecały pierwszym purytańskim kolonistom angielskim, tzw. „pielgrzymom”, którzy przybyli do USA w 1620 roku $^{5}$.

Tomasz M. Lebiecki, powołując się na Webera, wykazuje, że moralność protestancka w znacznym stopniu przyczyniła się do wykształtowania pojęcia self-made mana. Oznacza ono człowieka sukcesu zapewniającego sobie powodzenie dzięki własnym zdolnościom, staraniom oraz pracowitości. Za autora terminu uznaje się senatora Henry’ego Clay'a, który posłużył się nim podczas debaty senackiej w 1832 roku (Lebiecki 2008, 16).

Myślenie o Stanach Zjednoczonych jako o kraju, gdzie łatwo można się wzbogacić, wzmocniło się w XIX i XX wieku przez rozwój przemysłu, nowych technologii, kapitalizmu i wpływ korporacji. To wówczas fortun dorabiały się najbogatsze rodziny amerykańskie takie, jak Rockefellerowie, Du Pontowie oraz historyczni amerykańscy milionerzy, którzy zaczynali od zera - np. Henry Ford, którego matka miała belgijskich przodków, a ojciec pochodził z Irlandii, czy szkockiego pochodzenia Andrew Carnegie. Stali się oni symbolami self-made manów, a ich sylwetki pobudzały wyobraźnię oraz podtrzymywały złudzenie nieograniczonych możliwości gwarantowanych przez Amerykę. Do dziś w kontekście american dream popularna jest fraza "od pucybuta do milionera” (from rags to riches).

Warto zaznaczyć, że istotną rolę w tworzeniu się mitu sukcesu odegrała w USA literatura. Freeman Hunt w wydanej w 1856 roku książce Wartość i bogactwo sugerował pogodzenie cnotliwości z bogaceniem się, a pieniądz uznawał za wyznacznik pozycji społecznej. Jednym z najbardziej znanych popularyzatorów amerykańskiej literatury sukcesu był Horatio Alger Jr - autor ponad 100 publikacji o nakładzie 20 mln egzemplarzy. Powieści te należały głównie do literatury popularnej i były kierowane do młodzieży. Algera uznaje się za kontynuatora protestanckiej wizji sukcesu, w której bogactwo było nagrodą za godziwy sposób życia. Podobnie interpretowany

${ }^{5}$ Poczucie amerykańskiej wyjątkowości ma także swoje źródło w religii. Lebiecki, powołując się na książki Merryla Wyna Daviesa oraz Ziauddina Sardara American Dream. Global Nightmare, wskazuje, że Pilgrim Fathers utożsamiali się z potomkami plemion, które błąkały się po pustyniach Egiptu przed stworzeniem narodu izraelskiego. Stany miały być Nowym Izraelem oraz wcieleniem protestanckiej utopii, ziemią obiecaną; zob. Lebiecki Tomasz M., 2008, Mit o Ameryce - ziemi obiecanej, w: Zderzenie wewnątrz cywilizacji? Czyli o współczesnym spojrzeniu na Amerykański Sen $z$ perspektywy mniejszości latynoamerykańskiej $w$ Stanach Zjednoczonych, Opole, s. 13. Poczucie bycia wybranym przez Boga znajduje swoje odzwierciedlenie także w dyskursie politycznym. Przykładowo George W. Bush podczas kampanii wyborczej głosił publicznie hasła, że Ameryka jest krajem wybranym przez Boga do bycia wzorem dla świata. 
sukces można odnaleźć również w chrześcijańskiej literaturze amerykańskiej z lat 1860-1914, co wiązało się z tzw. ruchem „ewangelii społecznej”. August Jane Evans, Edward Payson Roe lub Gene Stratton Porter propagowali prosty obraz świata, w którym dobre uczynki miały pozytywne skutki, a złe negatywne konsekwencje.

Wraz z rozwojem kapitalizmu, przemysłu i urbanizacji oraz w erze wyparcia małych i średnich przedsiębiorstw przez korporacje mit sukcesu opierającego się na nieograniczonych możliwościach jednostki stał się bardzo odległy do rzeczywistości. Wiara w sukces nie zanikła, ale zmieniła swój charakter, co znalazło odzwierciedlenie w literaturze tworzonej przez reprezentantów Nowej Myślí, takich jak Ralph Wado Trine, Orison Swett Marden, Joseph E. Tuttle. Źródło sukcesu nadal było sprawą indywidualną, ale w filozofii tej poza pracą istotnym elementem życia człowieka był odpoczynek. Nowy obraz świata zdawał się bardziej optymistyczny, a jednostka miała skupiać się na rozwoju własnych talentów i zaufaniu swoim możliwościom - ludźmi sukcesu byli ci, którzy potrafili ukierunkować swój potencjał. Za przełomowego popularyzatora sukcesu uznaje się pastora Normana Vincenta Peale, który w latach 50. był bardzo aktywny medialnie. W 1952 roku wydał książkę Potęga myślenia pozytywnego, która długo była na drugim miejscu na liście bestsellerów zaraz po Biblii! Pastor wracał do mitologii obecnej u Algera przed przekształceniem jej przez Nową Myśl.

Najbardziej przystająca do rzeczywistości i osadzona w realiach pozostawała literatura naturalistyczna także traktująca o sukcesie. Pisarze, tacy jak Theodor Dreiser, Jack London czy David Graham Phillips przedstawiali świat, w którym bogacenie się to walka i wyścig bez końca lub fortuna dziedziczona. Jak wskazuje Osiatyński, bez względu na to, do którego nurtu przynależeli pisarze sukcesu, ich dzieła miały jeden wspólny mianownik - zdobycie bogactwa stawało się końcem losów bohaterów, podczas gdy w literaturze europejskiej dopiero początkiem i próbą przebicia się do wyższej warstwy społecznej. Historyk uznaje to m.in. za pokłosie braku feudalnej tradycji w amerykańskim społeczeństwie oraz uznanie pieniądza za jedyny wyróżnik pozycji społecznej (Osiatyński 1971, 84-110).

Emigrantów oraz uchodźców do wyprawy przez Atlantyk zachęcały zatem nie tylko równość i wolność gwarantowane prawnie, ale także marzenie o poprawieniu sytuacji materialnej podtrzymywane przez swobodę w zarządzaniu majątkiem, przekaz medialny, literacki oraz historie sukcesów jednostek, które wcześniej także przepłynęły ocean i zaczynały od zera:

Biedni imigranci chcieli przede wszystkim wolności od tych praw i zwyczajów, które hamowały w ich ojczyźnie indywidualną przedsiębiorczość gospodarczą. Była to wolność od pańszczyzny, od przypisania na stałe do jednego kawałka ziemi, jednego dziedzica i fornala. Była to wolność kupna i sprzedaży, możliwość uzyskania

${ }^{6}$ New Thought - ruch filozoficzny, który rozwijał się w Stanach pod koniec XIX wieku. Kluczowe dla tej filozofii było pojęcie „potęgi umysłu” (mind power) - stan umysłu bardziej wpływał na osiągnięcie sukcesu niż wcześniej cenione cechy charakteru. Zob. Osiatyński Wiktor, 1971, W kręgu mitu amerykańskiego, Warszawa, s. 91. 
różnorodnej pracy, uprawnienie do tego, by dzięki własnej pracowitości stać się bogatym lub z własnej winy pozostać biednym. Właśnie taki rodzaj wolności był uważany za źródło energii indywidualnej i dobrobytu społecznego (Osiatyński 1971, 80).

Dzięki ustanowieniu demokratycznego systemu politycznego oraz masowej emigracji Stany uznać można za społeczeństwo otwarte, które jako pierwszy zdefiniował Henri Bergson, wskazując głównie na ruchliwość społeczną oraz możliwość awansu. Karl Popper w pracy Społeczeństwo otwarte i jego wrogowie skupiał się natomiast na aspekcie ustroju państwowego, co warunkowało przestrzeganie takich zasad, jak tolerancja, racjonalność i niezależność od tradycji (Kołakowski 1984, 207). Różnorodność USA, postrzegana początkowo głównie w kontekście trzynastu kolonii, miała przerodzić się w prawdziwy tygiel kulturowy (melting pot) składający się z przedstawicieli nacji z całego świata. Jak zaznacza Danuta Mostwin, polska emigracyjna pisarka, z wykształcenia socjolog, teoria kotła zakładała, że różnorodne narodowości połączone ze sobą ideą stworzą na jednym terytorium zupełnie nowej jakości społeczeństwo. Emigrant miał zatem bezwarunkowo przyjmować wartości Nowego Świata i wręcz zostawał poczęty kulturowo na nowo jako Amerykanin. Odrzucając tę teorię, skazywał się na pozostawanie na społecznym uboczu oraz życie w getcie (Mostwin 1995, 18).

Na zakończenie rozważań o amerykańskim micie warto zaznaczyć, że pojęcie to jest stosunkowo młode. Autorstwo terminu przypisuje się historykowi oraz publicyście Jamesowi Truslowowi Adamsowi, który w popularnej książce The Epic of America (1931) w oryginalnym brzmieniu - the American Dream, użył go ponad 30 razy i rozpoczął tym samym karierę określenia na całym świecie. W prosty sposób oddawało ono zarówno nadzieje XVIIwiecznych purytanów ze statku Mayflower, Founding Fathers, jak i współczesnych uchodźców lub emigrantów. Szybko zadomowiło się w potocznej frazeologii także w Europie (Lebiecki 2010, 19-21).

Przedstawione powyżej główne elementy amerykańskiego mitu - równość, wolność i sukces w kontekście reportażu Małgorzaty Szejnert $W y s p a$ klucz można zanalizować na podstawie klasyfikacji wartości stworzonej przez Kimona Valaskakisa i jego zespół z Instytutu GAMMA w Montrealu. Badacze sformułowali trzy wymiary systemu wartości: na poziomie wierzeń, przekonań (wymiar paradygmatów), ideałów (normy moralne) oraz preferencji (jednostkowe upodobania) ${ }^{7}$. W tym ujęciu Stany Zjednoczone w sferze przekonań oraz ideałów deklarują to, co zapewnia demokracja. Szejnert przedstawia natomiast, jak przyjęte założenia były na przełomie wieków realizowane na poziomie personalnych wyborów, codziennych zachowań czy w obliczu zmian społecznych związanych ze wzmożonym, niespodziewanym napływem imigrantów. Wyspa klucz podważa wizerunek Stanów jako państwa „projektowanego” z myślą o demokratycznych

\footnotetext{
7 Badania Valaskakisa oraz jego zespołu cytuję za: Markowska Danuta, 1992, Dom - twierdza tożsamości, w: Dom we współczesnej Polsce, Łukasiewicz P., Siciński A. (red.), Wrocław, s. 196. 
ideałach. Prezentując autentyczne historie imigrantów i pracowników, reporterka dowodzi, że poziom preferencji nie przystawał do wymiaru paradygmatycznego.

\section{Selektywna równość}

Mit równości podważony zostaje w reportażu Szejnert najwyraźniej - przez stworzenie modelu imigranta pożądanego oraz tego niechętnie przyjmowanego czy wręcz zupełnie nieakceptowanego i przymusowo deportowanego do kraju ojczystego. Grupowanie przybywających odbywa się na podstawie kraju pochodzenia, stanu zdrowia oraz kompetencji mających w dalszej kolejności przełożyć się na produktywność nowego obywatela oraz jego wkład w rozwój gospodarczy amerykańskiego państwa.

Autorka wielokrotnie podkreśla przewagę pierwszej i drugiej fali emigracji (czyli do końca XIX wieku), która była mile widziana z wielu powodów. Początkowo w Stanach zwyczajnie brakowało taniej siły roboczej, a rozwijający się kraj oferował pracę zarówno w miastach, jak i w stanach rolniczych. Dodatkowo Brytyjczyków czy Skandynawów traktowano jako imigrantów bardziej perspektywicznych: z lepszym wykształceniem, oszczędnościami i umiejętnościami zawodowymi. Na „pierwszą imigrantkę”, która inauguruje działalność centrum imigracyjnego na wyspie Ellisa, świadomie przez Amerykanów wybrana zostaje młoda, pełna szyku i pogody ducha Irlandka - Annie Moore, której pomnik do dziś znajduje się na wyspie i w rodzimym kraju. „Pierwszy gość Ellis Island powinien budzić ciepłe, przyjazne uczucia wobec nowych przybyszy" (Szejnert 2009, 23). Dziewczyna to uosobienie optymizmu tak bliskiego wspomnianej literaturze sukcesu oraz możliwości, jakie stoją przed młodymi ludźmi szukającymi życiowych szans za oceanem. Annie Moore symbolizuje to, jakim krajem Stany chciały się stać, a tym samym jakich obywateli głównie „poszukiwały” - z krajów Zachodu o podobnych tradycjach do tych szerzonych przez pierwszych protestantów, w sile wieku i w pełnym zdrowiu, wyróżniających się, utożsamianych $\mathrm{z}$ radością oraz powodzeniem.

Zwrot ku konkretnym narodowościom nasilał się w różnych okresach. Związało się to m.in. z oficjalnymi regulacjami państwowymi. Selekcja i pęd ku przyjmowaniu imigrantów głównie z północnej Europy przykładowo wzrosło wyraźnie w 1924 roku, kiedy została wprowadzona druga ustawa kwotowa określająca skrupulatnie, że tylko $2 \%$ każdej narodowości zostanie wpuszczone do USA, a za rok bazowy przyjęto 1890, „co oznacza jeszcze większe przechylenie się kwot na rzecz danej, dobrej imigracji - angielskiej, irlandzkiej, niemieckiej" (Szejnert 2009, 180).

Przybysze z Europy Środkowej, Południowej i Wschodniej, czyli m.in. Polacy ${ }^{8}$, Rosjanie, Włosi, mieszkańcy rejonów bałkańskich byli utożsamiani

\footnotetext{
${ }^{8}$ Historyk Mieczysław Haiman wyróżnia trzy zasadnicze okresy polskiej emigracji do Stanów, tj. okres kolonialny 1608-1776, okres emigracji politycznej 1776-1865 oraz okres emigracji ekonomicznej 1865 do początków II wojny światowej. Danuta Mostwin uzupełnia to zestawienie o emigrację wrześniową po 1939, falę w połowie lat 60. oraz emigrację polityczną po 1981. Zob. Mostwin
} 
z biedą, zacofaniem i marnymi perspektywami - to właśnie ich symbolem jest brudna, zatłoczona oraz zbiurokratyzowana Ellis Island.

Plymouth Rock [skała, do której przybyli pierwsi imigranci w 1620 roku - MG] symbolizuje dobre pochodzenie. Potomkowie pielgrzymów z Mayflower należą do amerykańskiej arystokracji (...) Wyspa Ellisa nie jest skałą Plymouth. Jest ulepiona z gliny, mułu i popiołu. Wobec skały Plymouth i wszystkiego, co wyraża ten granit, wyspa jest kopciuchem (Szejnert 2009, 24).

Na mocy specjalnych ustaw z 1882 i 1885 roku zakaz wstępu do Stanów mieli Chińczycy i robotnicy kontraktowi. Już pierwszy komisarz ośrodka - pułkownik John Baptiste Weber - na samym początku swojej pracy otrzymał zadanie specjalne. Stany tak bały się napływu „gorszej jakości” imigrantów, że postanowiły wysłać go do Rosji w celu zbadania, dlaczego rosyjscy Żydzi oraz Polacy mogą chcieć dostać się do Ameryki. Pojawiały się sugestie, że:

żydowscy przybysze są na ogół zdegradowani, zacofani, słabi fizycznie i moralnie, niezdolni do włączenia się w życie amerykańskie i że mogą stać się ciężarem publicznym - a public charge. Będzie to przez mniej więcej dwadzieścia pięć lat najczęściej używany idiom na Ellis Island, potem ustąpi zbitce red scare - czerwona panika (Szejnert 2009, 18).

Wykluczenie następowało z równą siłą w związku z chorobami. Stany panicznie bały się cholery, trachomy czy wszy. Szejnert wskazuje szereg przykładów obrazujących ten strach - od zatrzymywania w porcie statków, których część pasażerów zachorowała podczas podróży, przez rozbudowane procedury badań medycznych, aż po niepodlegające negocjacji deportacje.

Lekarze pracujący na wyspie nosili mundury przypominające te wojskowe. Wielu kontrolowanym imigrantom, w tym Polakom, musiało to od razu nasuwać skojarzenia z opresją ze strony zaborcy. Obcokrajowcy byli zatem kwalifikowani pod względem zdrowia przez osoby uosabiające to, od czego Europejczycy uciekali - kontrolę, przymus, opresję ze strony państwa. Na biurokratycznej Ellis Island opracowano także procedury pozwalające na błyskawiczne wyłuskanie z tłumu ludzi potencjalnie chorych. Pierwszy etap selekcji polegał na sześciosekundowej obserwacji. Jak relacjonuje Szejnert, kiedy lekarz uznawał, że dana osoba wyglądała podejrzanie, rysował kredą na ubraniu przybysza właściwe oznaczenie, np. B - grzbiet (back), F - twarz (face), Pg - ciąża (pregnancy). Dziś nasuwa to oczywiste skojarzenia z oznaczeniem więźniów obozów koncentracyjnych.

Amerykanów martwiły nie tylko choroby fizyczne, ale także psychiczne. Komisarz Wiliam Williams wprost nazywa chorych umysłowo pasożytami, a doktor Thomas Salmon ich wydalenie „aktem profilaktyki wobec USA" (Szejnert 2009, 113):

Trzeba ich [chorych psychicznie - MG] wyłowić i zdecydować, czy mogą pozostać w Ameryce. Odpowiedź właściwie jest jasna - nie mogą pozostać. Ustawy

Danuta, 1995, Trzecia wartość. O formowaniu się nowej tożsamości polskiego emigranta w Ameryce, Lublin, s. 191. 
imigracyjne coraz bardziej ograniczają ich wstęp do Stanów. Najpierw eliminują obłąkanych i idiotów (ustawa z 1882 roku), następnie wszystkich idiotów i chorych psychicznie (1891), potem idiotów, epileptyków, aktualnie chorych psychicznie, osoby chore psychicznie w ciągu ostatnich pięciu lat oraz osoby, które miały jeden lub dwa ataki szaleństwa w jakimkolwiek poprzednim okresie (1903), imbecyli, osoby ograniczone umysłowo, osoby z psychicznymi defektami, które mogą im utrudniać zarabianie na życie (1907) (Szejnert 2009, 93).

Choć pojawiały się głosy, że przypadkowa selekcja oraz mechaniczne testy nie mogą decydować o przyszłości przybywających do Stanów imigrantów, Stany pod koniec XIX i na początku XX wieku nie mogły pozwolić sobie na dalszy zalew mało produktywnych Europejczyków. Rozbudowaną na Ellis Island biurokrację, związaną m.in. z kontrolą zdrowia przybywających, można interpretować jako pierwszą zaporę mającą ochronić Amerykę przed imigrantami czy uchodźcami, niebędącymi w stanie oddać się pracy na rzecz państwa. Uznawano, że obcokrajowcy z defektami zdrowotnymi są podwójnym obciążeniem dla budżetu rządowego - z jednej strony pozostają zupełnie niesamodzielni i nie nadają się do pracy zawodowej oraz zarabiania pieniędzy, z drugiej wymagają leczenia w szpitalach, a więc opieka nad nimi finansowana jest z podatków w pełni sprawnych obywateli. Mogą być ciężarem społecznym, powiększając środowiska przestępcze, lub mieć upośledzone potomstwo.

Pierwsza rzecz to rodzaj materiału ludzkiego, który kraje świata przysyłały do Stanów Zjednoczonych. Druga to rodzaj materiału ludzkiego, jaki Stany Zjednoczone akceptowały (Szejnert 2009, 93).

W praktyce zatem możliwość osiedlenia się w Ameryce XX wieku dostawali głównie ci, którzy pochodzili z preferowanych krajów, odznaczali się dobrym zdrowiem, ale także pewnymi oszczędnościami finansowymi (przymus opłacenia podatku na wyspie) oraz kompetencjami (deportowano analfabetów). Deklarowana „ziemia obiecana” okazywała się dostępna, ale nie dla tych, którzy prawdopodobnie najbardziej potrzebowali schronienia, bo w krajach ojczystych pozostawali biedni, prześladowani, schorowani oraz bez perspektyw poprawy swojego losu.

Wraz z napływem emigrantów w Stanach zmieniały się także nastroje społeczne. Nie wszyscy Amerykanie czuli potrzebę równego traktowania napływającej ludności. Rasizm rozwijał się nie tylko w stosunku do Murzynów, ale także skierowany był przeciwko Żydom, Słowianom, Włochom, Azjatom czy Latynosom. Moment krytyczny to wzmożony rozwój rasistowskiej organizacji $\mathrm{Ku}$ Klux Klan, która w roku przyjęcia drugiej ustawy kwotowej - jednocześnie w szczytowym momencie działalności organizacji - liczyła aż 4 miliony osób. Jej członkowie za rasę najwyższą uważali dawnych protestanckich białych Amerykanów ${ }^{9}$.

${ }^{9}$ Kontekstem dla tego zjawiska jest reportaż Katarzyny Surmiak-Domańskiej Ku Klux Klan. Tu mieszka miłość. 


\section{Wolność kontrolowana}

Wizerunek imigranta, jaki wyłania się z reportażu Szejnert, to również obraz osoby zniewolonej zarówno w sferze fizycznej przestrzeni, jak i ograniczających jednostkę zachowań innych ludzi (zniewolenie psychiczne).

W reportażu kilkukrotnie pojawiają się zaprzeczenia, że Ellis Island nie była więzieniem. W istocie jednak imigranci mieli prawo czuć się pozbawieni wolności $\mathrm{w}$ wielu sytuacjach, począwszy od wyruszenia w drogę ku Nowemu Światu. Większość z nich przybywała do USA na pokładzie steerage - najtańszej i najbardziej prymitywnej części statku, gdzie imigranci stłoczeni byli przez całą długą podróż przez Atlantyk. Brakowało nie tylko miejsca na ich bagaże, ale także urządzeń sanitarnych czy nawet zdrowej wody. „Amerykanie lepiej dbają o bydło, które wysyłają ze swoich portów, niż linie okrętowe o pasażerów" (Szejnert 2009, 88). Skupieni w ciasnej przestrzeni nie mieli wstępu do kabin czy pomieszczeń przeznaczonych dla bogatszych pasażerów - absolutnej mniejszości na większości parowców. Wskazuje to na brak poszanowania dla godności imigrantów, ale także jest dowodem, jak wykorzystywano ich desperację, naiwność, brak wyobraźni oraz wiedzy o realiach panujących w miejscach innych niż te, z których pochodzili.

Imigranci mogli być przetrzymywani na zatłoczonych statkach z kilku powodów: gdy istniało podejrzenie szerzenia się wcześniej wspomnianych chorób zakaźnych, kiedy na Ellis Island brakowało miejsca czy personelu do przyjęcia kolejnych przybyszy lub w chwili przekroczenia kwoty właściwej danej narodowości. Szejnert pęd statków, aby zdążyć wysadzić pasażerów w odpowiednim momencie, opisuje jako „szalone regaty”, a wyspę uznaje za „metę niezwykłych wyścigów.”

Dla wielu dosłownym więzieniem jest sama wyspa, na której czasem spędzają długie miesiące, oczekując na oficjalną decyzję, zaginione dokumenty czy wyzdrowienie. Kobiety w ciąży były czasem izolowane na wyspie tak długo, że rodziły na Ellis Island swoje dzieci. W centrum imigracyjnym warunki do codziennego życia były dalekie od arkadii, którą wyobrażali sobie imigranci. Wszędzie panował chroniczny brud, brakowało nie tylko łóżek, urządzeń sanitarnych czy wody, ale nawet wolnej przestrzeni. Mimo tych nieprzystających do masowego napływu ludności warunków Szejnert wskazuje na symptomy pozwalające myśleć, że imigranci wręcz „zadomawiają się" na wyspie. Świadectwem tego jest zbiorowe zdjęcie przy choince w czasie Bożego Narodzenia, stworzenie placu zabaw dla dzieci czy wprowadzenie możliwości wysyłki darmowych kartek pocztowych. Taka integracja pozwala wysunąć wniosek, że imigranci przymusowo zamknięci na wyspie stawali się społecznością scalaną przez wspólną niedolę, ale i oswajającą ją dzięki praktykowaniu znanych obyczajów lub choćby szczątkowemu kontaktowi z bliskimi. 
Wraz z napływem coraz większej liczby ludności na wyspie jednym z głównych zagrożeń stał się handel ludźmi. Zatrudniano nawet specjalnych pracowników socjalnych, którzy mieli śledzić handlarzy żywym towarem. Oznacza to, że część kobiet do Nowego Świata już przybywała zniewolona zarówno fizycznie przez przymusową podróż nadzorowaną przez konkretną osobę, jak i psychicznie (były zmuszane do prostytucji). Historie wykorzystywanych kobiet i ich tragicznego losu opisywał raport komisji senatora Dillinghama przygotowany dla Kongresu w 1909 roku:

Sprowadzanie i wykorzystywanie cudzoziemskich kobiet i dziewcząt dla niemoralnych celów i prostytucji - tak zwany handel białymi niewolnicami - jest najbardziej budzącą litość i najbardziej odrażającą stroną kwestii imigracyjnej (Szejnert 2009, 106).

Imigrantki szukające pomocy oraz życiowych szans, przez swą bezbronność, naiwność oraz brak znajomości zagrożeń w obcym miejscu, z pełnych odwagi i wiary w możliwość powodzenia „bohaterek” przeistaczały się w ofiary ginące bez wieści. Kobiety z Europy udające się do nowego kraju, często bez znajomości języka angielskiego, były bardziej podatne na oszustwa, co wykorzystywali handlarze, a czemu skutecznie nie przeciwdziałała amerykańska administracja.

Jako podsumowanie rozważań dotyczących wolności warto poddać analizie usytuowanie geograficzne Liberty. Statua Wolności zwrócona jest przodem do wpływających po dziś dzień do zatoki statków, czyli jej oczy spoglądają w kierunku południowym, gdzie Atlantyk łączy się z rzeką Hudson. Wyspa Ellisa znajduje się natomiast na północ od Liberty Island, a więc posąg stoi tyłem do niej. Dla imigrantów obraz wzniesionej pochodni był z jednej strony oznaką końca podróży, z drugiej także ostatnią chwilą, gdy pielęgnowany w ich świadomości mit mógł istnieć bez weryfikowania go w rzeczywistym świecie. W praktyce wolność „odwracała się” od zatrzymanych na wyspie, a wielu z nich na plecy Statuy patrzyło przecież przez długie miesiące. To przestrzenne ułożenie dwóch kluczowych wysp obrazuje również utopię ideałów w zestawieniu z preferencjami w rozumieniu Valaskakisa. Statua Wolności jawi się jako symbol amerykańskiej demokracji, a położona nieopodal Ellis Island jako punkt pogrzebania tych wartości przez selekcje, kontrole, zatrzymania czy deportacje.

\section{Ambiwalentny sukces}

Trudno jednoznacznie określić, czy prezentowani w książce emigranci odnieśli sukces. Dla wielu osób start w Nowym Świecie z niczym lub przy skromnej pomocy rodziny był nadal korzystniejszy niż pozostanie w ojczyźnie. Wielu przybywało do Ameryki z optymizmem, ale nie była to nadzieja na zbicie fortuny na miarę Henry`ego Forda, lecz raczej chęć zaspokojenia podstawowych potrzeb i realnych do osiągnięcia celów w postaci jakiejkolwiek stałej pracy zarobkowej. Szejnert przytacza przemawiające na korzyść amerykańskiej otwartości statystyki: w latach 1892-1954 do nowojorskiego 
portu przybyło ponad 16 milionów osób, wstępu odmówiono ok. 610 tys., co stanowi niespełna 4\% imigrantów. Oznacza to, że ponad 96\% osób faktycznie zostało do Stanów wpuszczonych i otrzymało szansę polepszenia warunków swojego życia. Sama statystyka świadczy o tym, że odsetek z różnych powodów odesłanych przybyszy był stosunkowo niewielki. Dzięki takim kalkulacjom Ameryka nadal prezentowała się jako kraj otwarty oraz tolerancyjny. Tłumacz Martoccia La Guardia pracujący na Ellis Island zanotował:

Naszą rekompensatą za uczestniczenie w scenach rozdzierających serce była, poza płacą, świadomość, że wielki procent ludzi napływających na Ellis Island prawdopodobnie da sobie radę i będzie cieszyć się lepszym życiem niż to, do którego nawykli tam, skąd przybyli (Szejnert 2009, 98).

Reportaż jest jednak także spisem wielu gorzkich historii oraz szeregu złamanych życiorysów. Takim przykładem jest Leie Kwarczinsky, która przypłynęła z trójką dzieci do USA, po czym okazało się, że ma jaglicę, a pracującego męża nie stać na kurację. Została deportowana do Rosji w dzień Wigilii. Zbigniew Korfanty spędził na Ellis pół roku w wyniku podejrzenia o współpracę z komunistami. Nie wrócił do swojego poprzedniego życia wycieńczony porzucił praktykę adwokacką i pracował na stacji benzynowej oraz w warsztacie samochodowym. Od nich Ameryka odwróciła się plecami tak samo jak Statua Wolności od tymczasowo zatrzymanych na wyspie Ellisa.

Jak wskazano w pierwszej części artykułu, amerykański mit wiązał się ściśle z podróżą na Zachód. Port w Nowym Jorku dla wielu przybyszy był tylko początkiem drogi. Większość udawała się w kierunku Zachodniego Wybrzeża lub do miejskich metropolii - Detroit, Chicago czy Pittsburgha. Amerykańscy przedsiębiorcy, obok skorumpowanych pracowników wyspy wyłudzających pieniądze czy wspominanych handlarzy kobietami, także wykorzystywali niską świadomość i ostrożność imigrantów. Przykładowo na billboardach reklamowali Dakote jako krainę złotego ziarna, choć w rzeczywistości potrzebowali robotników do budowy linii kolejowych. W przekazie reklamowym Kalifornia rysowała się jako kraj możliwości z prawie 44 milionami akrów niezagospodarowanej ziemi rządowej, która miała być idyllą dla farmerów, a przecież na przełomie wieków XIX i XX mitologizowana wędrówka na Zachód pierwszych osadników dobiegła końca.

Sukces ma więc w reportażu Szejnert charakter ambiwalentny. Przez pryzmat warunków panujących na wyspie oraz personalnych, pojedynczych historii imigrantów, imigracja do USA rysuje się raczej jako uciążliwa, przymusowa tułaczka bez gwarancji rozpoczęcia lepszego życia. Liczby oraz fakt, że Ameryka do dziś jest wymarzonym krajem emigracji dla wielu Europejczyków, podtrzymują skutecznie mit sukcesu.

\section{Ellis Island jako miejsce pamięci}

Szejnert nie opowiada tylko o ludziach, ale także, a może nawet przede wszystkim, o miejscu. Stąd też historii Ellis Island nie zamknęła na roku 
1924, kiedy wyspa przestała być głównym centrum imigracyjnym. Dwa ostatnie rozdziały o wymownych tytułach - „Martwa fala” i „Poławiacze” poświęciła czasom, kiedy Stany Zjednoczone oswajały się z wydarzeniami minionego wieku oraz dojrzewały do chwili, aby pamięć o kluczowych falach imigracji pielęgnować.

Architekci czy instytucje publiczne miały wiele pomysłów, jak zagospodarować wyspę, gdy straciła ona swoją dawną funkcję - jak zaznacza Szejnert - bez ceremonii zamknięcia. Mimo że inicjatyw było sporo, to zwykle okazywały się one płonne, kosztowne i przez wiele lat Ellis Island przypominała złomowisko, którego z czasem pilnował już tylko jeden stróż. I tak wyspa mogła stać się domem dla starców, bezdomnych, nieletnich przestępców, parkiem rekreacyjnym, międzynarodowym centrum handlowym czy supernowoczesnym oraz samowystarczalnym miastem. Ostatecznie jednak wspólnie z Liberty została monumentem historii USA, a na jej terenie otwarto muzeum, gdzie - jak podaje reporterka - jedna trzecia załogi pochodzi z rodzin, które przeszły przez wrota Ameryki na wyspie.

Ellis Island w aktualnym kształcie można nazywać miejscem pamięci, które Pierre Nora definiuje jako konkretne miejsce, gdzie wspólnoty rozumiane jako naród, grupy etniczne czy rodziny przechowują swoje pamiątki lub uznają owo miejsce za element swojej osobowości (Rybicka 2014, 311).

Muzeum na Ellis Island realizuje i jedną, i drugą funkcję. To nie tylko gabloty z kuframi, elementami wyposażenia czy materiałami z nagranymi wypowiedziami przybywających do Stanów imigrantów, ale także przestrzeń, która kształtuje tożsamość grupy oraz jej wizerunek - „nikt nie podniesie ręki na historyczny dobytek wyspy, bo Ellis przybliża się coraz bardziej do skały w Plymouth" (Szejnert 2009, 273).

Reportaż Szejnert rozpoczyna się i kończy jak legenda czy baśń - opowieścią o Indianach i ostrygach. Ta klamra kompozycyjna sugeruje, że za wszelką nietolerancję i wykluczenie odpowiada człowiek opierający swoje opinie na przesądach oraz uprzedzeniach, które rzutowały na sposób traktowania imigrantów. Woda w Zatoce Nowojorskiej staje się jednak coraz czystsza, co stanowi odniesienie do procesu coraz większego zrozumienia dla losów imigrantów i uchodźców XX wieku. Uznanie Ellis Island za ważne historycznie miejsce oraz nadanie jej odpowiedniej rangi może dawać także nadzieję, że różnorodność obyczajów, jakie zaczęły panować w Ameryce wraz z napływem imigrantów, nie będzie traktowana jako zagrożenie.

W zakończeniu reportażu Małgorzata Szejnert podkreśla, że w Polsce nie znalazła żadnych materiałów o Ellis Island. Jej praca - reporterska, analityczna oraz historyczna - pozwala uważać również samą Wyspę klucz za miejsce pamięci według definicji Elżbiety Rybickiej, badaczki specjalizującej się w problemach z zakresu zwrotu przestrzennego:

Literatura nie tylko mówi o miejscach pamięci, ale sama staje się miejscem pamięci. To określenie można rozumieć dwojako, po pierwsze w perspektywie intertekstualnej tak jak proponuje Wolfgang Iser: „Przechowywanie fragmentów wyrwanych 
z innych tekstów należy rozumieć jako próbę ocalenia przeszłości przed jej ostateczną zagładą." (...) Po drugie, literatura może być interpretowana jako miejsce pamięci w perspektywie restytucji przeszłości, aktywnego i sprawczego przypominania tego, co zapomniane i wyparte. W tym przypadku jest nie tyle wzorcem pamięci kulturowej, ile medium formatywnym, aktywnie oddziałującym na dane kultury pamięci (Rybicka 2014, 323).

Polacy także masowo emigrowali do Ameryki, a reportaż Szejnert stanowi uwiecznienie ich historii. Katarzyna Frukacz odnajduje w Wyspie klucz trzy zasadnicze ujęcia Polaka emigrującego do Stanów: z perspektywy personelu (obserwacje), blokowanej carskiej korespondencji oraz przynależności do nowego kraju i wkładu we współczesną historię wyspy (w wypadku Polaków wpuszczonych do USA) (Frukacz 2016, 274-278). Dzieło to stało się zatem ważnym w dorobku literatury polskiej punktem wskazującym na zaangażowanie polskich imigrantów w kształtowanie się amerykańskiego państwa wielonarodowego. Dodatkowo to jeden z niewielu reportaży literackich wydanych po 1989 roku, który nie przedstawia USA z perspektywy narratora pierwszoosobowego skupionego na anegdotach podróżniczych i własnych przeżyciach ${ }^{10}$.

\section{Zakończenie}

Stany Zjednoczone w reportażu Szejnert są państwem niejednorodnym oraz pełnym sprzeczności. Jak zauważa Monika Wiszniowska, reporterka $\mathrm{z}$ jednej strony prezentuje ten kraj jako pełen entuzjazmu, dumy z demokracji oraz pionierskich pomysłów, co obrazują przykładowo odwołania do Statuy Wolności. Z drugiej jednak historia samej wyspy Ellisa jest zaprzeczeniem tolerancji, otwartości oraz liberalizmu (Wiszniowska 2016, 268-269).

Wyspa klucz dowodzi, jak względne znaczenie ma amerykańska demokracja ustalona przez Deklarację niepodległości Stanów Zjednoczonych oraz jak szybko po powstaniu zjednoczonego narodu mit upadł. Historia pokazała także, że idea całkowitej asymilacji stała się ułudą, a przybywający do Stanów nie wyzbywali się swojej tożsamości narodowej. Reportaż obrazuje początek podziału amerykańskiego narodu na podgrupy, który istnieje do dziś, a nieudana integracja z XIX i XX wieku, także z czarną ludnością, której migracja jest właściwie zupełnie oddzielną historią ${ }^{11}$, odciska piętno na współczesnej amerykańskiej polityce, stosunku do uchodźców, zagadnieniach społecznych oraz nastrojach obywateli. Małgorzata Szejnert poprzez historię Ellis Island pokazuje dwuznaczną politykę migracyjną USA oraz praktyki postępowania wobec imigrantów nacechowane wyższo-

${ }^{10}$ Przeważające są teksty reporterskie zaliczane do popularnej literatury podróżniczej, np. Wałkowanie Ameryki Marka Wałkuskiego czy Droga 66 Doroty Warakomskiej. Monika Wiszniowska oprócz Wyspy klucz do najnowszych reportaży literackich traktujących o USA włącza jeszcze reportaże Pawła Smoleńskiego Opowieści amerykańskie oraz wspomniany Ku Klux Klan. Tu mieszka miłość Katarzyny Surmiak-Domańskiej (Wiszniowska 2016, s. 260). Do tego zestawienia warto dodać wydany w 2013 roku Nowy Jork. Od Manahatty do Groud Zero Magdaleny Rittenhouse oraz Nowy Jork. Przewodnik niepraktyczny Kamili Sławińskiej (2015).

11 Temat pozycji społecznej oraz migracji Murzynów porusza cytowany Wiktor Osiatyński w opracowaniu Korzenie „Korzeni.” Dzieje Murzynów w Stanach Zjednoczonych. 
ścią, a nawet hipokryzją. Głównym motywem przyjmowania imigrantów nie były chrześcijańskie czy demokratyczne ideały, tylko gospodarcze potrzeby szybko rozwijającego się państwa. W tym ujęciu koncepcja państwa otwartego ma wymiar w znacznym stopniu utopijny.

Jest więc Ameryka orkiestrą wielu instrumentów, jest mozaiką rozlicznych kolorów, jest bukietem kwiatów zebranych we wszystkich niemal zakątkach świata. Jest Ameryka obojętna i Ameryka przyjacielska. Ameryka przestępców i gangsterów i Ameryka misjonarzy i ludzi poświęcających się bezinteresownie. Ta krańcowość i różnorodność istniejących obok siebie „ameryk” jest tą prawdziwą Ameryką. (...) Ameryka była i jest krajem pluralistycznym. Ziemią emigrantów (Mostwin 1995, 131).

\section{Bibliografia}

Frukacz Katarzyna, 2016, „Czymże sa nasze niepokoje przy ich niepokojach?” Historyczne fale emigracji polskiej do Stanów Zjednoczonych w reportażach Małgorzaty Szejnert, w: Literatura polska obu Ameryk. Studia i szkice. Seria druga, Szałasty-Rogowska B. (red.), Katowice, s. 273-283.

Huntington Samuel, 2007, Amerykańska tożsamość, w: Kim jesteśmy? Wyzwania dla amerykańskiej tożsamości, Pietrzyk B. (przeł.), Kraków, s. 43-129.

Kołakowski Leszek, 1984, Samozatrucie otwartego społeczeństwa, w: Czy diabeł może być zbawiony i 27 innych kazań, wyd. 2, Londyn, s. 206-216.

Lebiecki Tomasz M., 2008, Mit o Ameryce - ziemi obiecanej, w: Zderzenie wewnątrz cywilizacji? Czyli o współczesnym spojrzeniu na Amerykański Sen $z$ perspektywy mniejszości latynoamerykańskiej w Stanach Zjednoczonych, Opole, s. 13-52.

Markowska Danuta, 1992, Dom - twierdza tożsamości, w: Dom we współczesnej Polsce, Łukasiewicz P., Siciński A. (red.), Wrocław, s. 196-216.

Mostwin Danuta, 1995, Trzecia wartość. O formowaniu się nowej tożsamości polskiego emigranta $w$ Ameryce, Lublin.

Osiatyński Wiktor, 1971, W kręgu mitu amerykańskiego, Warszawa.

Rybicka Elżbieta, 2014, Topografie historii: miejsce, pamięć, literatura, w: Geopoetyka. Przestrzeń i miejsce we współczesnych teoriach i praktykach literackich, Kraków, s. 297-324.

Scheffer Paul, 2010, Druga ojczyzna. Imigranci w społeczeństwie otwartym, Jusewicz-Kalter E. (przeł.), Wołowiec.

Szejnert Małgorzata, 2009, Wyspa klucz, Warszawa.

Weber Max, 2010, Etyka protestancka a duch kapitalizmu, w: Etyka protestancka a duch kapitalizmu. Protestanckie „sekty” a duch kapitalizmu, Baran B, Miziński P. (przeł.), Warszawa, s. 23-133.

Wiszniowska Monika, 2016, Obraz Stanów Zjednoczonych we współczesnym reportażu polskim. Rekonesans, w: Literatura polska obu Ameryk. Studia i szkice. Seria druga, Szałasty-Rogowska B. (red.), Katowice, s. 257-271.

Żyro Tomasz, 1994, Boża plantacja. Historia utopii amerykańskiej, Warszawa. 


\section{O Autorce:}

Magdalena Gajek - doktorantka na Wydziale Filologii Polskiej i Klasycznej Uniwersytetu im. Adama Mickiewicza w Poznaniu. Pracuje nad rozprawą doktorską dotyczącą kreacji przestrzeni wyobrażonej i doświadczonej Nowego Jorku w nowoczesnym reportażu polskim. Kluczowe dla niej zagadnienia to geopoetyka, ze szczególnym uwzględnieniem roli miasta, oraz tożsamość imigrantów. Promotorką rozprawy jest dr hab. Monika Brzóstowicz-Klajn z Zakładu Semiotyki Literatury WFPiK UAM. 